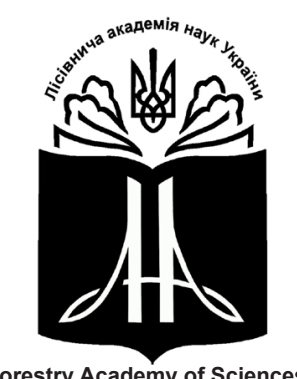

Forestry Academy of Sciences of Ukraine

Наукові праці Лісівничої академії наук України Proceedings of the Forestry Academy of Sciences of Ukraine

http://fasu.nltu.edu.ua https://doi.org/10.15421/411918

Article received 2018.09.20

Article accepted 2019.03.28
ISSN 1991-606X print

ISSN 2616-5015 online

(a) $\triangle$ Correspondence author Ihor Soloviy

soloviy@yahoo.co.uk

General Chuprynka st., 103, Lviv, 79057, Ukraine

УДК 502.33:630

\title{
Лісова політика у міждисциплінарному науковому контексті: тренди та перспективи розвитку
}

\author{
І.П. Соловій
}

Досліджено та узагальнено характерні тренди розвитку лісової політики як наукової дисципліни. На основі аналізу процесів зміни парадигми лісової політики та економіки лісокористування, суспільних змін і глобальних проблем поглиблено розуміння теоретико-методологічної сутності та економічного змісту лісової політики, як сучасної наукової дисиииліни, ї̈ взаємозвязки з іншими дисичплінами і особливості понятійного відображення різних інтерпретацій. Систематизовані епістемологічні підходи до лісової політики та економіки лісокористування. Узагальнено наукові підходи, характерні для досліджень з лісової політики, на основі огляду наукових праць як стосовно неї, так і в ширшому контексті публікацій з екологічної та природоохоронної політики. Обгрунтовано перспективи розгортання досліджень з лісової політики, зумовлені ї̈ важливістю для вирішення актуальних проблем, на які інші науки не дають відповіді: аналіз взаємних впливів політик різних секторів та їхньої взаємодії, інституційний аналіз, вивчення ринків, соціально-економічні дослідження ставлення різних категорій і груп населення до послуг лісових екосистем, вивчення потреб зацікавлених сторін.

Ключові слова: аналіз лісової політики; екологічна економіка; зміна парадигми; менеджмент сталого лісового господарства; послуги лісовмх екосистем.

Вступ. Вагомою перепоною для сталого розвитку лісового господарства і лісового сектору загалом є відсутність сформульованої мети і пріориттетів лісової політики, яка в Україні досі не оформлена законодавчо i на практиці переважно лишень реагує post factum на різноманітні чинники суспільного впливу. Така ситуація зумовлює потребу розробити теоретико-методологічні засади формування суспільно узгодженої лісової політики та їі впровадження за допомогою системи інструментів.

Лісова політика розвивається у низці країн, щонайменше - століття, водночас як наука і як процес управління, тобто у межах двох основних вимірів наукового (теоретичного) і прикладного (практичного). Формування національної лісової політики у контексті глобалізаційних процесів, новітніх тенденцій міжнародної та європейської лісової політики, а, водночас, і трансформаційних процесів в на- ціональній економіці вимагає зосередження більшої уваги на лісовій політиці як науковій дисципліні.

Об'єкти та методика дослідження. Об' $\epsilon$ 'кm дослідження - процеси формування галузевої (секторальної) політики розвитку лісового сектора економіки, тобто лісової політики. Предмет дослідженьтеоретичні і прикладні еколого-економічні аспекти формування лісової політики та системи відповідних інструментів. Мета роботи - розробка теоретикометодологічних основ і концептуальних рішень проблеми формування науково обгрунтованої лісової політики та інструментів іiі впровадження.

Систематизація теоретичних положень i розробка на їхній основі методології формування лісової політики та їі інструментального забезпечення уможливлена завдяки комплексному використанню методів емпіричного і теоретичного рівнів пізнання, включаючи загальнонаукові методи досліджень:

Соловій Ігор Павлович - академік Лісівничої академії наук України, віце-президент ЛАН України, доктор економічних наук, професор кафедри екологічної економіки. Національний лісотехнічний університет України, вул. генерала Чупринки, 103, м. Львів, 79057, Україна. Тел.: 032-287-03-88, +38-097-284-08-81. E-mail: soloviy@yahoo.co.uk ORCID: https://orcid.org/0000-0001-5885-6264 
системний підхід, структурно-функціональний, нормативний, порівняльний та інституційний аналіз, методи порівняння та аналогій. Для досягнення мети дослідження на різних його етапах застосовано дисциплінарний, міждисциплінарний i трансдисциплінарний пізнавально-методологічний інструментарій. На мультидисциплінарному рівні інтегровано односторонні доповнення однієї наукової дисципліни іншою. Ми виходили 3 того, що лісова політика та економіка лісового господарства різні, але споріднені наукові дисципліни. Спорідненість зумовлена тим, що, відповідно до міжнародних класифікацій, ці науки належать до соціальних, пов'язані з поведінкою людини і функціонуванням суспільства, мають спільну історію (про що свідчить поняття «політична економія»), a, водночас, різні основи в галузі фундаментальних для цих дисциплін політичних та економічних наук. Основні ж відмінності лісової політики та лісової економіки зумовлені їхньою спрямованістю. В економіці увагу зосереджено на аналізі поведінки економічних агентів (людей, домогосподарств, фірм, державного сектору), а також їхньої взаємодії на ринках. У політиці увага акцентується на аналізі політики, яка впливає на функціонування господарських суб'єктів і на процесах, результатом яких стає державна політика, зокрема політика щодо галузей економіки.

Дослідження грунтується на усвідомленні факту, що на сучасному історичному етапі взаємопов'язаного розвитку світу (природи, суспільства і людини) усі актуальні проблеми мають складний характер, що вимагає виходу за межі дисциплінарних обмежень. Методологія базувалась на ідеї, що економіка лісокористування, яку традиційно розглядають як частину економіки природних ресурсів, повинна, як і лісова політика, інтегрувати підходи трансдисциплінарного наукового напряму екологічної економіки.

Результати досліджень. Грунтовні праці з лісової політики, в яких викристалізувались теоретичні основи іiі як науки, опубліковані на початку минулого століття в Німеччині (von Enders, 1905, Weber, 1926). За означенням М. Ендерса, вміщеним у першій відомій нам книзі з лісової політики, виданій в Німеччині «...лісова політика є вченням про суспільне та економічне значення лісу і лісового господарства для держави і народного господарства» (von Enders, 1905). У перевиданні книги (1922 р.) додано: «Лісова політика як наука є вченням про передумови і умови, в яких лісове господарство найповніше і найкраще виконує свої загальнонаціональні та приватні господарські завдання. Лісова політика як прикладна економічна політика і галузь практичного державного господарства охоплює громадські і приватні механізми, що мають за мету пряме чи опосередковане сприяння лісовому господарству» (von Enders, 1922). Німецький вчений цього ж періоду H. Weber зазначав, що «...під лісовою політикою як наукою потрібно розуміти наукове обгрунтування місця, яке відводить держава лісовому госпо- дарству у структурі національної економіки. Лісова політика має справу з суспільною значущістю лісу та розглядає ліс і пов'язані з ним дії (лісівництво, лісовпорядкування, лісове товарознавство та ін.), як такі, що мають промислово-технічну природу. Лісова політика є частиною суспільно-економічної, особливо державно-економічної діяльності, що має справу 3 лісовою галуззю. Ця діяльність за сво$\epsilon ю$ сутністю є частково обмежувальною, частково спрямованою на збереження лісів, а частково - на догляд за ними...» (Weber, 1926).

Від моменту започаткування лісової політики як наукової дисципліни від неї очікували виконання двох завдань: по-перше - представництва інтересів лісового господарства у суспільстві, по-друге - покращання емпіричних знань стосовно того, як лісова політична система функціонує. Ці завдання знайшли відображення у двох наукових школах лісової політики: перша - зорієнтована на онтологічнонормативний аспект досліджень і спрямована, насамперед, на вирішення практичних проблем лісового господарства та політичне сприяння його розвиткові, друга - на емпірично-аналітичний аспект, a, саме, регулювання конфліктів різних інтересів щодо лісів у суспільстві. У німецькомовному регіоні Свропи яскравим представником онтологічнонормативної школи був Victor Dieterich, який прийшов у науку з сфери виробництва, і вважав, що лісова політика - наука, яка має обслуговувати інтереси менеджерів лісового господарства, тобто бути його лобістом (Dieterich, 1953). Ця школа зфокусувала увагу на загальносуспільних функціях лісів. Зауважимо, що саме Dieterich запровадив у 1930-х роках термін «функції лісів».

На противагу цьому нова (емпірично-аналітична) школа виходила 3 того, що різні члени суспільства мають різні інтереси щодо лісів. На важливості їх врахування вперше наголосив Пітер Глюк (Glück, 1976, 1982), вважаючи це основною концепцією для досліджень у галузі лісової політики. Цей підхід згодом став домінувати і більшість досліджень 3 лісової політики у Німеччині, Австрії та Швейцарії стали базуватись на постулаті, що процес лісової політики може бути проаналізовано лише за результатами виявлення всіх суспільних інтересів щодо лісів. У руслі цього підходу Max Krott розглядає лісову політику як процес соціальних переговорів, що регулюють конфлікти інтересів у використанні й охороні лісів згідно 3 програмами лісового сектора (Krott, 2005). На понятті «конфліктів інтересів» побудоване і визначення К.-R. Volz: «Лісова політика - це цілеспрямована діяльність 3 наміром впорядкувати стосунки і конфлікти інтересів між суспільством, лісом і лісовим господарством для спільного блага» (Volz, 1997).

В англомовній літературі, поряд із терміном «лісова політика» (forest policy), використовують термін «лісоресурсна політика» (forest resources policy). Саме під такою назвою вийшла у світ книга американського вченого F. Cubbage, який вважає, що «...лісоресурсну політику можна розглядати як 
цільовий курс дій чи взаємодій, які здійснює особа чи група осіб, відповідно до їхнього інтересу стосовно лісових ресурсів. Лісова політика визначає як будуть використовуватись ліси (зазвичай, для досягнення певного стану). Політика також визначає, хто отримає вигоду від лісокористування і хто компенсує витрати, пов'язані із веденням лісового господарства» (Cubbage et al, 1993).

На думку A. Worrell, «Лісова політика - це певні особливі принципи стосовно використання суспільством лісових ресурсів, дотримання яких робить внесок у досягнення певних цілей цього суспільства» (Worrell, 1970, с. 26). Цей автор розрізняе політику щодо лісового господарства (forestry policy), сфокусовану на політичних питаннях, пов'язаних із лісогосподарською практикою (наукове обгрунтування ведення господарства в лісах для тривалого отримання продукції та послуг) і лісову політику (forest policy), яка охоплює і розглядає всі політичні аспекти, пов'язані з впливом на ліси (зокр., політику щодо землекористування). P. Ellefson, досліджуючи закономірності процесу розвитку і запровадження лісової політики, розглядає iї як «...загально узгоджений і цілеспрямований курс дій, що має важливі наслідки для багатьох людей і для значного числа й обсягу природних ресурсів» (Ellefson, 1992, с. 15).

В. Husch у «Вказівках з формування лісової політики», виданих FAO, вбачає у лісовій політиці водночас «загальні чи специфічні цілі, що ідентифікують інтереси та цілі уряду стосовно використання й розвитку національних лісових ресурсів; презентацію державної програми діяльності у сфері лісового господарства; опис усіх видів діяльності, що суттєво впливають на використання та менеджмент лісів, які перебувають як у державній, так і приватній власності» (Husch, 1987, с. 4).

M. Gane, аналізуючи зацитовані означення лісової політики F. Cubbage, B. Husch i A. Worrell критикує їх за те, що вони стосуються лише лісових ресурсів, а не лісового сектора загалом, цілей та використання лісів, тобто процесу, що поєднує цілі розвитку з досягненням сектором очікуваних змін. На його думку, «...національну лісову політику можна порівняти з іншими галузевими політиками, такими як сільськогосподарська, промислова чи освітня.... Підходити до формування лісової політики потрібно, зосереджуючись загалом на постулатах щодо іiі цілей, а не на сприйнятті іiї процесу...» (Gane, 2007, c. 292).

J. R. Nascimento характеризує лісову політику як таку, що «спрямована на збільшення внеску лісових земель у суспільний добробут» (Nascimento, 2005 , с. 57). Це коротке визначення змістовне в економічному сенсі, оскільки автор вийшов за вузькі межі інтересів сектора і розглядає лісові землі в цілому як джерело суспільного добробуту. Згаданий автор розрізняє види політики залежно від особливостей їх внеску в суспільний добробут і пов'язаності з приватними чи суспільними товарами та послугами.
За визначенням I. Synakevych, «Лісова політика - це сукупність принципів та інструментів, які використовують національні та наднаціональні органи, політичні партії і громадські організації для відстоювання своїх інтересів у галузі відтворення, охорони й використання лісових ресурсів» (Synakevych, 2004, с. 5). Вчений трактував лісову політику як розділ економіки лісокористування, в якому розглядають принципи лісокористування та економічні, екологічні, соціальні й технологічні інструменти, використовувані для втілення в життя цих принципів.

Ye.V. Miseshinin, розглядаючи питання формування механізму екологізації раціонального використання та збереження лісових ресурсів, розрізняє екологічно зорієнтовану лісову політику i екологічну політику в лісовому секторі економіки (називаючи іiї ще екологічною лісовою політикою (Miseshinin, 2004).

Лісова політика - наука, що інтенсивно розвивається, а тому динамічно змінюється і розуміння ï сутності. Цю тенденцію Е. Köpf характеризує так: «Класичними питаннями лісової політики раніше були: сталість постачання лісової продукції, запобігання девастації лісів, охорона природи, $\mathrm{i}$, наприклад, в Німеччині - право кожного громадянина на доступ у ліси з метою відпочинку..., тепер актуальними стають інші проблеми, такі як потреба активізувати, пробудити політиків для того, щоб вони усвідомили довготермінові аспекти лісових екосистем і лісовирощування» (Köpf, 2000).

У лісовій політиці та економіці лісокористування доречно виділити такі епістемологічні підходи: неопозитивістський, онтологічно-нормативний, інтерпретаційний та історико-діалектичний. Вони різняться за своїми припущеннями щодо таких питань: а) що є реальним з наукових припущень? б) як трактувати суспільні цінності? в) як формувати на їхній основі лісову політику?

Неопозитивістський підхід (інші назви: емпірично-дедуктивний, гіпотетико-дедуктивний) наукові дослідження обмежує емпіричними спостереженнями. В рамках цього підходу об'єктивність науки базується на її зверненні до фактів, а демаркація наукового від ненаукового здійснюється методом «проб і помилок», а не шляхом перевірки гіпотез. Так звані ненаукові (нормативні) питання можуть трактуватись як гіпотези стосовно конкуруючих цінностей. Перевага надається кількісним підходам (наприклад, оцінці ефективності, дієвості). Неопозитивістський підхід розглядає лісову політику як регулювання конфліктів різних інтересів у лісокористуванні.

Онтологічно-нормативний підхід виходить 3 того, що реальне $є$ прихованим і сутність речей полягає у відкритості для наукового осмислення («реального визначення»). Сутність політики формування суспільного порядку задля загального блага. Основними цінностями вважають доступ до знань. Вчені пропонують політичні рішення, які повинні бути застосовані, щоб легітимізувати прак- 
тичну політику. Відмінність між науковим і політичним баченням проблем вважається незначною. Перевага надається історичному і якісному методам досліджень. Лісова політика за такого підходу зосереджена на забезпеченні суспільної підтримки лісового господарства.

Інтерпретаизійний підхід виходить 3 того, що світ побудований на соціальних або дискурсивних засадах і суспільні явища не існують поза нашою їх інтерпретацією. Можна «зрозуміти» сенс суспільних явищ, не пояснюючи їх (герменевтичний підхід). Концепція «сенсу рішень» передбачає, що наукові істини - це щось більше за результат, підтверджений емпірично експериментами і випробуваннями. Ці істини - це наукові інтерпретації чи переконання, засновані на своєрідному «сплаві» технічних і соціальних рішень. Оскільки згідно цього підходу вважається, що об'єктивний аналіз суспільних явищ неможливий, то завданням вчених є самостійні дослідження в рамках визначеного дискурсу. Роль політичного аналізу зводиться до функції модератора та консультанта. Роль вченого полягає у вивченні соціальних конструкцій шляхом розробки «нарративу» і «сюжетної лінії». У методологічному плані увага зосереджена на якісних підходах дискурсивної теорії. Визначення лісової політики як науки зосереджено на розумінні сенсу окремих форм лісокористування для суспільства.

Історико-діалектичний підхід (інші назви: історико-матеріалістичний, історико-критичний) це більшою мірою ідеологізований підхід, який базується на тоталітарному баченні історичного процесу як розвитку, спрямованого на досягнення «безкласового суспільства». Основними проблемами вважаються матеріалістичні протиріччя між трудовим класом і капіталістами. Завдання науки розглядаються крізь ідеологічну призму так званого служіння трудовому класу і побудови безкласового суспільства. Завдання лісової політики бачиться, насамперед, у забезпеченні народного господарства продукцією.

Класифікація сучасних наукових досліджень 3 лісової політики дає змогу виділити три основних їхніх напрями: а) дослідження в межах правового поля лісової політики, тобто з погляду юридичної перспективи; б) дослідження, які базуються на підходах політичних наук; в) дослідження економічної перспективи із застосуванням еколого-економічних підходів. Дослідження, які базуються на підходах політичних наук, сприяють вивченню передумов, що вплинули на іï формування 3 акцентуванням уваги на впливах, a, особливо, учасниках, які визначають iii пріоритети, а також безпосередній їі зміст (рис.).

Для аналізу традиційних проблем лісової політики переважно застосовують принципи некласичної економіки, які жорстко критикують представники екологічної економіки (Costanza, 1991, Daly \& Farley, 2003). У межах економічної перспективи дослідження 3 лісової політики були зосереджені, насамперед, на деревині як лісовому ресурсові, однак впродовж останніх років спектр досліджень значно розширився.

Зростання екологічної свідомості і сприйняття немонетарних «м'яких вартостей» лісів ведуть до того, що лісова політика дедалі тісніше інтегрується 3 екологічною, кліматичною та енергетичною, метою яких є корегувати вади ринку, пов' язані з наявністю зовнішніх ефектів та існуванням прерогатив загальносуспільного добробуту. На наш погляд, запровадження принципів екологічної економіки в теоретичні основи лісової політики вимагатиме адаптації до трендів розвитку комерційних ринків послуг лісових екосистем та зростання вагомості їхніх соціальних функцій.

У табл. узагальнено наукові підходи, характерні для досліджень 3 лісової політики, на основі огляду наукових праць як стосовно неї, так і у ширшому контексті публікацій з екологічної та природоохоронної політики.

Таблицяя

Наукові підходи у дослідженнях лісової політики

Науковий підхід

Історичний

Прагматично-плюралістичний

Міжгалузевий (міжсекторальний)

Структурний підхід

(політекономічний)

Антропології політики і влади

Інструментальний / зосереджений на змісті
Сутність досліджень зміни політики в часі

3'ясування впливу суспільних груп на політику, визначення політичної доцільності управлінських рішень

Дослідження впливу лісового сектора на політику інших секторів економіки та їхньої взаємопов'язаності

Аналіз сфер впливу основних політико-економічних груп, що визначають політику

Дослідження політичних позицій, поглядів та владних можливостей усіх учасників

Аналіз і рекомендації щодо змісту політики, iii інструментів і механізмів 


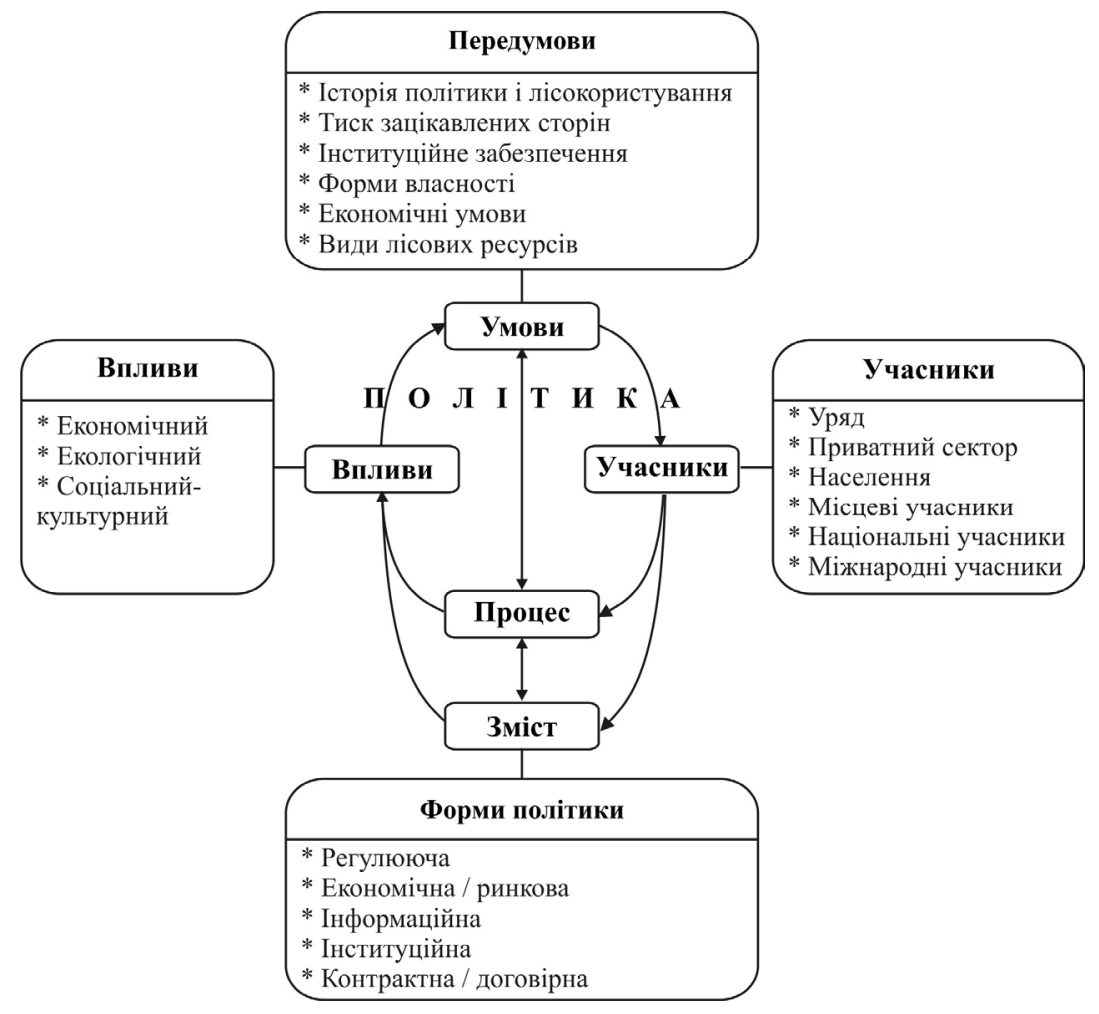

Рис. Чинники, які визначають пріоритети досліджень $з$ лісової політики

Виконаний аналіз засвідчив, що найпоширенішими в науковій літературі $€$ підхід раціонального вибоpy і підхід, зосереджений на змісті політики («rational choice» and «content-focused» analyses - англ.); значну частку займає i прагматично-плюралістичний підхід («pragmatic pluralist'» approach - англ). Водночас дедалі більшого значення набувають інструментальний та міжгалузевий підходи, що зумовлено потребами координації діяльності різних секторів задля вирішення таких нагальних проблем, як зміна клімату, збіднення біорізноманіття та втрата потенціалу послуг лісових екосистем.

Впродовж останніх трьох десятиліть суспільне бачення значення лісів докорінно змінилося. Ліси вже не розглядають як виключно джерело отримання деревини, а як комплексні екосистеми, які підтримують існування життя на планеті, роблять внесок у розвиток сільських територій, подолання бідності, збереження біорізноманіття та стійкості екосистем, забезпечують широкий спектр продукції та послуг. А це потребує нових підходів і до лісової політики.

Теоретично, державна політика повинна забезпечувати баланс суспільних інтересів щодо збереження лісів, їх використання і відтворення на найпроблемніших територіях. Однак у реальному житті шлях для досягнення цієї мети пролягає від 3'ясування причин лісових конфліктів на місцевому рівні до аналізу процесів глобалізації ринку, потоків капіталів і технологій.

Розвиток лісової політики у $\mathrm{XX}$ ст. тісно пов'язаний $з$ підходами, започаткованими у США, які можна охарактеризувати, як спробу забезпечити найбільше благ для якомога більшої кількості користувачів. Ідеї першого керівника Лісової служби США Гіффорда Пінчота, засновника цього підходу, отримали розвиток у багатьох країнах. J. Fedkiv зауважив, що лісова політика дедалі більше уваги приділяє природоохоронному аспекту, що є наслідком збільшення і урізноманітнення потреб суспільства в продуктах, послугах і цінностях лісів; набуття нових наукових знань, що визначають комплексність менеджменту екосистем для різноманітних цінностей (Fedkiv, 1996).

Деякі автори характеризують цей тренд як перехід до пост-модерного менеджменту природних ресурсів. Відбулась зміна парадигм: спершу перехід від політики, базованої на державній власності та державному регулюванні до підходів, базованих на ринковій економіці, а згодом від них - до підходів, базованих на інтересах громад і концепції сталого розвитку. На наш погляд, ці парадигми не витіснили одна одну, а навпаки - спричинилися до кумулятивного ефекту, який полягає у поєднанні різноманітності політичних й управлінських альтернатив - командно-контрольних, саморегулятивних і стимулювальних, спроможних інтегруватися відповідно до політичного контексту.

Постмодернізм як теорія, що суттєво вплинула на лісову політику, в економічній діяльності полягає у переході від звичних форм власності до комплексного їх поєднання та виникнення нових категорій, від традиційної детерміністичної науки - до системи багатоцільових знань, від визнання лише державних інтересів - до поєднання інтересів різних суспільних груп. 
Змінилось не лише суспільне сприйняття ролі лісів, але й підходи до управління ними. На зміну механістичному (тобто технократичному, позбавленому розуміння сутності природних процесів) підходу прийшов так званий органічний підхід, який передбачає узгодження господарських рішень із законами функціонування екосистем (Kennedy et al, 1998). Замість редукціоналізму, тобто максимально спрощеного прагматичного розуміння, набув поширення голістичний підхід, який полягає у врахуванні широкого кола функцій лісів.

Зростання потреби у соціальних і екологічних вигодах від лісів зумовлює громадський тиск на державні структури, відомства і підприємства, відповідальні за ведення лісового господарства. У минулому такі структури були ключовою, або й єдиною інстанцією на лісополітичній арені, яка поєднувала функції менеджера, власника, судді й інструктора. Наростання тиску громадськості змушує державні структури зосереджуватись на двох останніх функціях, тоді як приватний сектор і громадськість переймають на себе усі інші.

Суспільне усвідомлення соціокультурної ролі лісів спонукає до досліджень, результати яких можуть використовуватись у стратегіях лісової політики. Так, у Шотландії ліси розглядають як інструмент збереження національної ідентичності і самоорганізації громад. Тому вивчають можливості їх залучення до планування лісокористування. Особливу увагу звертають на соціальні інновації місцевих громад, як вагомий чинник їхнього добробуту (Sarkki et al., 2019).

Під час формування лісової політики потрібно брати до уваги сучасні виклики, пов'язані з станом довкілля. Найпоширенішими $є$ два критеріальні підходи до визначення вагомості впливів довкілля і впливів на довкілля у лісовій політиці - соиіальний, спрямований на максимізацію загальних соціальних ефектів, зокрема, врахування екологічних аспектів в економічних розрахунках та біоцентричний - заснований на парадигмі порушень у природних системах (Adamovich \& Veeman, 1998). Згідно 3 першим підходом, лісогосподарське виробництво генерує ефекти поза сферою компетенції ринкової системи. Під час господарських заходів виникають зовнішні ефекти (як позитивні, так і негативні), зумовлені змінами середовища існування лісової фауни, впливом на якість вод, структуру ландшафту, рекреаційні ресурси і т. ін. 3 огляду на перспективу якомога повнішого використання лісових ресурсів, ці елементи розглядатимуть як цілісність, тому прибутки від лісогосподарського виробництва, чи будь-які інші позитивні ефекти аналізують 3 погляду їхньої вартості та будь-яких негативних ефектів, спричинених виробничою діяльністю. Так званий постулат «соціального планування» $є$ фундаментальним для економічного аналізу суперечливих питань лісокористування. Він лежить в основі багатьох національних лісових політик і базується на потребі максимізувати суспільні вигоди від використання лісових ресурсів. До уваги беруть не лише прибутки від економічної діяльності, але й вигоди, що пов'язані з довкіллям.

На стадії ухвалення рішень актуалізуються питання ефективності та справедливості аллокації ресурсів. Природне довкілля розглядають (поряд 3 капіталом та робочою силою) як складову частину ресурсів, від яких залежить забезпечення суспільства товарами та послугами. Підхід, що грунтується на врахуванні інтересів довкілля в лісовій політиці, застосовується достатньо давно, проте він не позбавлений суперечностей, пов'язаних зі складністю оцінки багатьох вартостей чи вигід. Проблема визначення вартостей, пов'язаних з рекреаційною діяльністю, мисливством, рибальством, недеревинними ресурсами лісу, полягає у складності самого аналізу та збору потрібної інформації.

У XXI ст. набула поширення парадигма лісової політики, яка зосереджує увагу на екологічних аспектах лісового середовища. Цей підхід базується на парадигмі природних порушень (Natural Disturbance Paradigm) і біоцентричному підході, заснованому на гіпотезах моделі спадковості в екосистемах із зосередженням уваги на еталонах природних ландшафтів та біорізноманітті. Такий менеджмент забезпечує впорядкованість екосистеми, однак не обов'язково забезпечує виробництво необхідних суспільству товарів та послуг.

Якщо суспільство не зорієнтоване на досягнення сталості, тоді результати підходу, заснованого на врахуванні природних порушень, та підходу, який базується на соціальній моделі, будуть однакові. Якщо ж воно захоче розподілити ризики від втрати екологічної інтегрованості на всі компоненти вартості, тоді ці підходи будуть відрізнятися. До негативних аспектів підходу менеджменту екосистем можна віднести те, що він ігнорує потребу досягнення суспільного балансу, прагнучи досягти лише екологічно-оптимальних лісових умов. Ми вважаємо, що компромісною позицією, яка поєднає менеджмент екосистем та антропоцентричний менеджмент, буде стан рівноваги, який враховуватиме більшість проблем лісового господарства та охорони довкілля.

Перспективи розгортання досліджень 3 лісової політики зумовлені ії важливістю для вирішення проблем, на які інші науки не дають відповіді. Адже такі дослідження дають змогу відвернути конфлікти, сприяють аналізу перспектив розвитку сектора, допомагають ідентифікувати деформації, виниклі під час запровадження політики і виявити причини неефективних рішень і негативних результатів, діапазон можливостей для вдосконалення та вказати на можливі реформи (Chandrasekharan, 2002).

Аналіз взаємних впливів політик різних секторів та їхня взаємодія з лісовою політикою і того, як вони впливають на досягнення основних національних цілей, може допомогти гармонізувати як економічну, так і екологічну політику і забезпечити їхню інтеграцію.

Інституційний аналіз допомагає визначити характер і фази інституційної реструктуризації - напр., 
децентралізації. Дослідження потенційної ролі залучених у лісову політику організацій і методів їхньої діяльності дають змогу ідентифікувати потреби і можливості інституційного будівництва, партнерства, реструктуризації бюрократичної системи.

Вивчення ринків (доступність, мінливість, вплив на збереження ресурсів) важливі для визначення цілей політики щодо лісогосподарського виробництва. Інвестиції в лісове господарство і деревообробну промисловість також пов'язані із ситуацією на ринку лісопродукції.

Соціально-економічні дослідження щодо ставлення різних категорій і груп населення до послуг лісових екосистем, вивчення потреб зацікавлених сторін дасть змогу збалансувати цілі політики, впорядкувати стратегії та заходи, забезпечити чітку перспективу щодо ролі лісового сектора в подоланні соціальних проблем, викорінити прояви корупції, здійснюючи це послідовно, відповідно до принципів сталого розвитку.

Висновки. Лісова політика як наукова дисципліна еволюціонувала, інтегрувавши наукові підходи суміжних наукових дисциплін і продовжує розвиватися у руслі пошуку рішень нових суспільних потреб і соціальних змін, глобальних екологічних викликів, нової політичної та економічної реальності.

У лісовій політиці доречно виділити такі епістемологічні підходи, які визначають сутність наукових досліджень: неопозитивістський, онтологічнонормативний, інтерпретаційний та історикодіалектичний.

Аналіз сучасних наукових досліджень 3 лісової політики дає змогу здійснити їхню класифікацію, виділивши три основних тренди: дослідження в межах правового поля лісової політики, тобто 3 погляду юридичної перспективи; дослідження, які базуються на підходах політичних наук; дослідження економічної перспективи лісової політики, які, зокрема, отримали розвиток унаслідок застосування еколого-економічного підходу. Запровадження принципів екологічної економіки в теоретичні основи лісової політики передбачає визначення екологічних обмежень лісокористування, охоплення комерційних ринків екосистемних послуг лісів та врахування вагомості їхніх соціальних функцій.

Сучасні моделі екологізації економіки доволі різноманітні (Dubovich et al., 2018). Зокрема відповідно до Цілей Сталого Розвитку ООН до 2030 року, все більшої політичної уваги та зацікавленості дослідників набуває концепція біоекономіки замкненого циклу. Ця нова концепція передбачає ефективніше управління відновлюваними ресурсами на біологічній основі шляхом інтеграції принципів економіки замкненого циклу в біоекономіку (Dalia, et al., 2019). Ці ідеї повинні бути осмислені на теоретичному рівні на предмет їх інтеграції у бізнес-моделі та політику сталого розвитку лісового сектору.

У дослідженнях лісової політики отримали поширення такі наукові підходи: історичний, прагматичноплюралістичний, міжгалузевий (міжсекторальний), структурний підхід, політекономічний, інструментальний та антропології політики і влади. Дослідження процесів лісової політики сприяють виявленню перспектив розвитку лісового сектора і його плануванню.

Аналіз взаємних впливів політик різних секторів, їхньої взаємодії з лісовою політикою та аналіз того, як вони впливають на досягнення основних національних цілей розвитку, може допомогти узгодити як економічну, так і екологічну політику і забезпечити їхню інтеграцію.

Збільшення і урізноманітнення потреб суспільства у продуктах, послугах і цінностях лісів у поєднанні з усвідомленням виснаження ресурсів і погіршення стану довкілля зумовили зміну парадигми менеджменту природних ресурсів, що знайшло відображення у теоретичному розвитку лісової політики як науки.

Дослідження лісової політики є і будуть потрібними для успішного здійснення «зміни парадигми» на шляху до сталого розвитку. Втілення в життя нових концепцій лісової політики, методів управління та створення й реорганізації чинних інституцій допоможе запровадженню ефективних реформ.

\section{Бібліографічні посилання}

Adamovich, W.L., \& Veeman, T.S. (1998). Forest Policy and the Environment: Changing Paradigms. Canadian Public Policy - Analyse de Politiques, Vol. XXIV Supplement / Numero Special 2, p. 52-61.

Cubbage, F.W., \& Newman, D.H. (1993). Forest Resource Policy. New York: John Wiley \& Sons, Inc. Chandrasekharan, C. (2002). The Need for Forest Policy Research and Articulation. Paper presented at the IUFRO Science/Policy Interface Task Force regional meeting held in Chennai, India at the M.S. Swaminathan Research Foundation, 16-18 July 2002. - 14 p.

Costanza, R., Daly, H. E., \& Bartholomew, J.A. (1991). Goals, Agenda and Policy Recommendations for Ecological Economics. Ecological Economics: the science and management of sustainability / edited by Robert Costanza. - New York, Columbia University Press, p. 1-21.

Daly, H. E., \& Farley, J. (2003). Ecological Economics: Principles and Applications. Island Press.

Dalia, D., Veijonahoa, S., \& Toppinen, A. (2019). Towards sustainability? Forest-based circular bioeconomy business models in Finnish SMEs. Forest Policy and Economics, https://doi.org/10.1016/j. forpol.2018.12.004

Dietrich, V. (1953). Forstwirtshaftpolitik. Hamburg und Berlin.

Dubovich, I., Adamovsky, A., Vasylyshyn, K., Soloviy, V. (2018). Contemporary models for greening of economics: concepts, unity, contradictions and directions for interaction. Proceedings of the Forestry Academy of Sciences of Ukraine, 17, 158-164. https:// doi.org/10.15421/411831 (in Ukrainian). 
Ellefson, P. V. (1992). Forest resources policy: process, participants, and programs. McGraw-Hill, Inc., pp. $15-16$.

Fedkiw, J. (1998). Managing Multiple Uses on National Forets 1905-1995. A 90-year Learning Expirience and Isn't Finished Yet. - Washington DC: USDAForest Service.

Gane, M. (2007).Forest strategy. Strategic Management and Sustainable Development for the Forest Sector. Dordrecht: Springer.

Glück, P. (1976). Die Rolle der Verbände in der theoretischen Forst- und Holzwirtschaftspolitik, Habilitationsschrift Universität für Bodenkultur. Wien.

Glück, P. (1982). Contribution of forest spatial planning to a regional spatial policy. Allgemeine Forstzeitung, 93, 1-8 (in Deutsch).

Husch, B. (1987). Guidelines for forest policy formulation. FAO Forestry Paper 81, Food and Agriculture Organization of the United Nations, Rome.

Kennedy, J. J., Dombeck, M.P., Koch, N.E. (1998). Values, beliefs and management of Public Forests in the Western world at the close to the twentieth century. Unasylva, 192 (49), 16-26.

Kopf, E.U. (1995). Socio-Economic Considerations in Changes to Forest Management Practices. International Forestry Seminar «Exploring Multiple Use and Ecosystem Management: From Policy to Operational Practices». FAO/ECE / ILO Proceedings, British Columbia, Canada; September 9-15, pp. 141-148.

Krott, M. (2005). Forest policy analysis. Dordrecht: Springer.

Miseshinin, Ye.V. (2004). Ecological economic preconditions for transformation of forest ownership. Scientific works of the DonNTU, series Economic, 69, 131-136 (In Ukrainian).

Nascimento, J.R. (2005). Forest Vocation Lands and Forest Policy: When Simpler is Better. RUR-05-03. Washington, D.C.: Inter-American Development Bank.

Sarkki, S.; Ficko, A.; Miller, D.R.; Barlagne, C.; Melnykovych, M.; Jokinen, M.; Soloviy, I.; \& Nijnik, M. (2019) Human values as catalysts and consequences of social innovations. Forest Policy and Economics, 104, 33-44.

Synakevych, I. M. (2004). Forest policy. Lviv: IZMN (In Ukrainian).

Von Enders Max (1922). Handbuch der Forstpolitik mit besonderr Berück Sichtinung der Gesetsyebung und Statistik. Zweite, newberarbeitete Auflage. Berlin: Verlag Von Julius Springer,

Weber, H. (1926). Forstpolitik. Berlin: Verlag Von Paul Parey.

Worrell, A. C. (1970). Principles of Forest Policy. New York: McGraw-Hill book company.

Volz, K.-R. (1997). Forest use concepts and their forestry assessment. Forstwissenschaftliches Centralblatt, 116, 291-300 (in Deutsch).

\section{Лесная политика в междисциплинарном научном контексте: тренды и перспективы развития}

\author{
И.П. Соловий
}

На основании анализа процессов изменения парадигмы экологической и лесной политики, экономики лесопользования, общественных изменений и глобальных проблем углублено теоретикометодологическую сущность и экономическое содержание лесной политики, как современной научной дисциплины, ее взаимосвязи с другими дисциплинами и особенности понятийного отражения разных интерпретаций. Систематизированы эпистемологические подходы к лесной политике и экономике, научные подходы к исследованиям в сфере лесной политики, предложена их классификация. Обобщены подходы к исследованиям, которые имеют отношение к исследованиям в области лесной политики, основанные на обзоре научных работ как в этой сфере, так и в более широком контексте публикаций по вопросам экологической и природоохранной политики. Обоснованы перспективы развертывания исследований по лесной политике в связи с ее важностью для решения насущных проблем, на которые другие науки не дают ответов: анализ взаимного влияния политики в различных секторах экономики и их взаимодействия, институциональный анализ, исследование рынков, социально-экономические исследования отношения различных категорий и групп населения к услугам лесных экосистем, изучение других потребностей заинтересованных сторон в лесах и их продукции.

Ключевые слова: анализ лесной политики; экологическая экономика; изменение парадигмы; менеджмент устойчивого лесного хозяйства; услуги лесных экосистем.

Соловий Игорь Павлович - академик Лесной академии наук Украины, вице-президен ЛАН Украины, доктор экономических наук, профессор кафедры экологической экономики. Национальный лесотехнический университет Украины, ул. генерала Чупринки, 103, г. Львов, 79057, Украина. Тел.: 032-287-03-88, +38-097-284-08-81. E-mail: soloviy@ yahoo.co.uk ORCID: https://orcid.org/0000-0001-5885-6264 


\section{Forest Policy in the Interdisciplinary Scientific Context: Trends and Development Prospects}

\section{Soloviy ${ }^{1}$}

The article explores and generalizes the characteristic trends of forest policy development as scientific discipline. Taking into account tendencies of the processes of environmental and forest policy and forest economics paradigm shift, social changes and global problems, the understanding of theoretical essence and economic content of forest policy as a modern scientific discipline and its interrelationa with other disciplines, epistemological approaches to forest policy studies systemized. Main research fields in forest policy are overviewed and their classification proposed. The approaches that are relevant to forest policy studies are generalized on the basis of relevant scientific papers review and in the wider context of publications on environmental and conservation policies. The prospects for forest policy studies development are explained due to its importance for solving the urgent

Ihor Soloviy - full Member of the Forestry Academy of Sciences of Ukraine, vice-president of the Ukrainian Forestry Academy of Sciences, Doctor of Economic Sciences, Professor of the Department of Ecological Economics. Ukrainian National Forestry University, 103 General Chuprynka st., Lviv, 79057, Ukraine. Tel.: 032-287-03-88, +38-097-284-08-81. E-mail: soloviy@yahoo. co.uk ORCID: https://orcid.org/0000-0001-5885-6264 problems that other sciences do not give answers: the analysis of mutual influences of policies in different sectors and their interaction, institutional analysis, the study of markets, socig-economic research of the needs in forest products and attitudes towards forest ecosystem services of the different categories and groups of stakeholders.

Analysis of modern scientific research on forest policy allows us to make their categorization, highlighting the three main trends: research within the legal field of forest policy, that is the point of view of the legal prospects; research that are based on political sciences perspective; a study of the economic prospects of the forest policy, in particular such studies base on the application of ecological economics approach. The introduction of the principles of ecological economics into theoretical fundamentals of forest policy call for determination of ecological boundaries (restrictions, limitations) of forest exploitation, coverage of commercial markets for ecosystem services and taking into account the role of their social functions. In line with the SDGs of the UN 2030 Agenda, the circular bioeconomy concept is considered as gaining greater policy research interest. This new concept implies a more efficient resource management of bio-based renewable resources by integrating circular economy principles. Therefore its ideas have to be conceptualized at theoretical level for forest sector business models and policies.

Key words: forest policy analysis; ecological economics; paradigm shift; Sustainable Forest Management; forest ecosystem services. 